\title{
Sea-level fluctuations and coastal evolution in the state of Rio de Janeiro, southeastern Brazil
}

\author{
JOÃO WAGNER A. CASTRO ${ }^{1}$, KENITIRO SUGUIO ${ }^{2}$, JOSÉ C.S. SEOANE ${ }^{3}$, \\ ALINE M. DA CUNHA ${ }^{4}$ and FABIO F. DIAS ${ }^{5}$ \\ 1,4,5 Laboratório de Geologia Costeira, Sedimentologia e Meio Ambiente/LAGECOST, Museu Nacional, \\ Universidade Federal do Rio de Janeiro/ UFRJ, Quinta da Boa Vista, São Cristovão, 20940-040 Rio de Janeiro, RJ, Brasil \\ ${ }^{2}$ Instituto de Geociências, Universidade de São Paulo, Rua do Lago, 562, Cidade Universitária, 05580-080 São Paulo, SP, Brasil \\ ${ }^{3}$ Departamento de Geologia, Universidade Federal do Rio de Janeiro, \\ Avenida Athos da Silveira Ramos, 274, Cidade Universitária, Ilha do Fundão, 21941-916 Rio de Janeiro, RJ, Brasil
}

Manuscript received on February 3, 2014; accepted for publication on May 5, 2014

\begin{abstract}
The present paper aims to investigate the relative sea-level and the coastal evolution during the Holocene in the Rio de Janeiro coastline, based on geological and biological indicators. Using topographic survey, excavation and coring, and ${ }^{14} \mathrm{C}$ dating of these coastal deposits and beachrocks outcrops, we have reconstructed a sealevel curve for the Holocene. For the first time on the Brazilian coast it was identified a negative record of relative sea-level during Late Pleistocene and Early Holocene transition. After the transition, a relatively rapid increase of sea-level began. At approximately at $8500 \mathrm{cal} \mathrm{yr} \mathrm{BP}$, the sea-level was $0.5 \mathrm{~m}$ below the current level, was overtaken for the first time in the Holocene, at approximately $7500 \mathrm{cal}$ yr BP. The maximum level of $+2.5 \mathrm{~m}$ was reached between 4770 and $4490 \mathrm{cal} \mathrm{yr}$ BP. At the point of maximum transgression, the sealevel began a general behavior of lowering until the present. These results confirm other data already obtained elsewhere along the Atlantic coast of South America. The results of this study are consistent with previous researches and they help to refine the Holocene sea-level record along the Brazilian coast.
\end{abstract}

Key words: Sea-level fluctuations, Coastal evolution, Holocene, Brazilian coast.

\section{INTRODUCTION}

The Southern Hemisphere exhibits well-documented, higher-than-present Holocene sea-level events, as can be found in South Africa (e.g., Miller et al. 1993, Ramsay 1995), Australia (e.g., Belperio 1995, Baker and Haworth 2000), and South America (Porter and Stuiver 1984, Martin et al. 1985, Isla 1989, Cavalotto et al. 2004). Suguio et al. $(1985,1988)$ and Suguio (1993) have presented

Correspondence to: João Wagner Alencar Castro E-mails: jwacastro@gmail.com / castro@mn.ufrj.br several sea-level curves for the Brazilian coast based on more than 700 radiocarbon dates.

Fluctuations in the relative sea-level during the Holocene were important in the construction and evolution of the Brazilian coastal plains (Martin et al. 1997). These factors were investigated by Roncarati and Neves (1976), Martin et al. (1984), Suguio and Tessler (1984), Suguio et al. 1985, Flexor et al. (1984), Martin et al. (1985), Suguio and Martin (1985), Villwock (1994), Angulo and Lessa (1997), Turcq et al. (1999), Suguio (1999, 2003a, b), and Castro and Suguio (2010). 
Along the coast of Rio de Janeiro, Lamego (1945) was the first to provide a general description of the life cycle of the lagoons and the lateral growth of sandy spits associated with changes in the sea-level. Martin et al. (1984) conducted the first radiocarbon $\left({ }^{14} \mathrm{C}\right)$ dating in the Jacarepaguá coastal plain in the city of Rio de Janeiro. This information elucidated the relative sea-level variations within southeastern Brazil. Martin et al. (1997), in their work Coastal Quaternary Geology of the North Coast of the State of Rio de Janeiro and Espírito Santo, have provided information on the relative sea-level changes and distribution of Quaternary marine and lagoon deposits along the coast of these respective states. The marshland of northeastern Rio de Janeiro was flooded by the sea in $5100 \mathrm{cal}$ yr BP. After the maximum holocenic transgression, a lagoon system was formed and established behind the barrier islands. Lowering of the sea-level to 4900 cal yr BP resulted in desiccation of the lagoons and their concurrent filling and replacement by wetlands (Castro et al. 2009).

The aim of this paper is to present, for the first time, the curve of Holocene sea-level (MSL) in Rio de Janeiro based on data from biological and geological indicators and compare then other curves obtained along the Atlantic coast of South America. According to Suguio et al. (1985), the main pieces of evidence for changes in the sealevel during Quaternary period are as follows: Geological (Quaternary sandy deposits of marine origin that are situated above sea level today represent unquestionable evidence of bygone sealevels). Biological (This evidence is represented by fouling vermetids, barnacles, corals, and urchins holes that are located above the current level of life of these organisms, thereby indicating sea levels above the present).

ENVIRONMENTAL SETTING

The Southeast of Brazil has been classified as a passive margin since the opening of the
South Atlantic at about $130 \mathrm{Ma}$. In that area, the predominant rocks are Precambrian-Cambrian granites and gneisses, formed during the Brasiliana orogeny between 700 to $450 \mathrm{Ma}$ (Sadowski and Dias Neto 1981). The result of this orogenic process is a makeable structural framework which comprises a complex arrangement of dominantly NE-SW trend foliation and shear zones plus N-S faults and fractures approximately parallel to the coastline (Zálan and Oliveira 2005).

The investigated area comprises the Fluminenses Lakes region in the central coast area of the state of Rio de Janeiro, southeastern Brazil (Fig. 1). In this site, there are two distinct geological domains: 1) basements and 2) Cenozoic sedimentary covers. The basement rocks are characterized by headlands consisting of felsic ortho-gneisses, orthoamphibolites, and metasediments intercalated with amphiboles. Alkaline intrusions of the MesozoicCenozoic (Schmitt 2001) also exist. Cenozoic covers are sediments from both the continent (Barreiras Formation) and the coast, consisting of deltas, estuaries, beaches, beach ridges, dunes, lakes, lagoons, marshes, and beachrocks (Castro et al. 2009).

Studies on the relative sea-level variations identified the former positions of beach lines referring to the last Holocene transgression in the coast of Rio de Janeiro. The transgression peak occurred approximately between 4590 and 5100 cal yr BP. The marine level was $3.0 \mathrm{~m}$ above the current, resulting in a large paleolagoon (Dias 2009). In front of the paleolagoon, barrier-island and beach-ridge systems were formed. As the sea-level lowered, the lagoon environment was transformed into marsh areas (Martin et al. 1997, Castro et al. 2012). The occurrence of marine terraces composed of sand and gravel from the weathering of headlands is associated with this transformation (Turq et al. 1999). The inner continental shelf of the region is covered by medium-to-fine sand and a narrow neck of mud that extends to a depth of $25 \mathrm{~m}$ (Silva et al. 2011). 
The wave climate consists of predominantly good weather in the northeastern quadrant. The occurrence of anticyclone swells from the South Atlantic Ocean is associated with eastsoutheastern polar cold fronts (Silva 2009). The study area is located in a micro-tidal region of the Brazilian coast. The tidal regime is asymmetrical and semi-diurnal, with a highest tide of $1.0 \mathrm{~m}$ and low tides between 0.06 and $0.025 \mathrm{~m}$, referencing the tide reduction $(0.67 \mathrm{~m})$ by the Navy of Brazil (Silva 2009).

In this region, the phenomenon of oceanographic coastal upwelling is generated by northeastern winds, which are produced by an atmospheric center of semi-permanent high pressure over the South Atlantic Ocean, thereby producing cold waters that are rich in nutrients. Some sea-surface anomalies, such as negative temperatures caused by the wind direction in coastal upwelling, are present on the continental shelf of southeastern Brazil, especially during the summer (Gyllencreutz et al. 2012). When northeastern winds persist for several days, a strong upwelling may occur with the decrease in the sea surface temperature (up to $15^{\circ} \mathrm{C}$ ) near the coast of Cabo Frio, in the region of the Fluminenses Lakes. These temperatures are approximately $10^{\circ} \mathrm{C}$ cooler than in other sites of the southeastern Brazilian coast (Fonseca 2012).
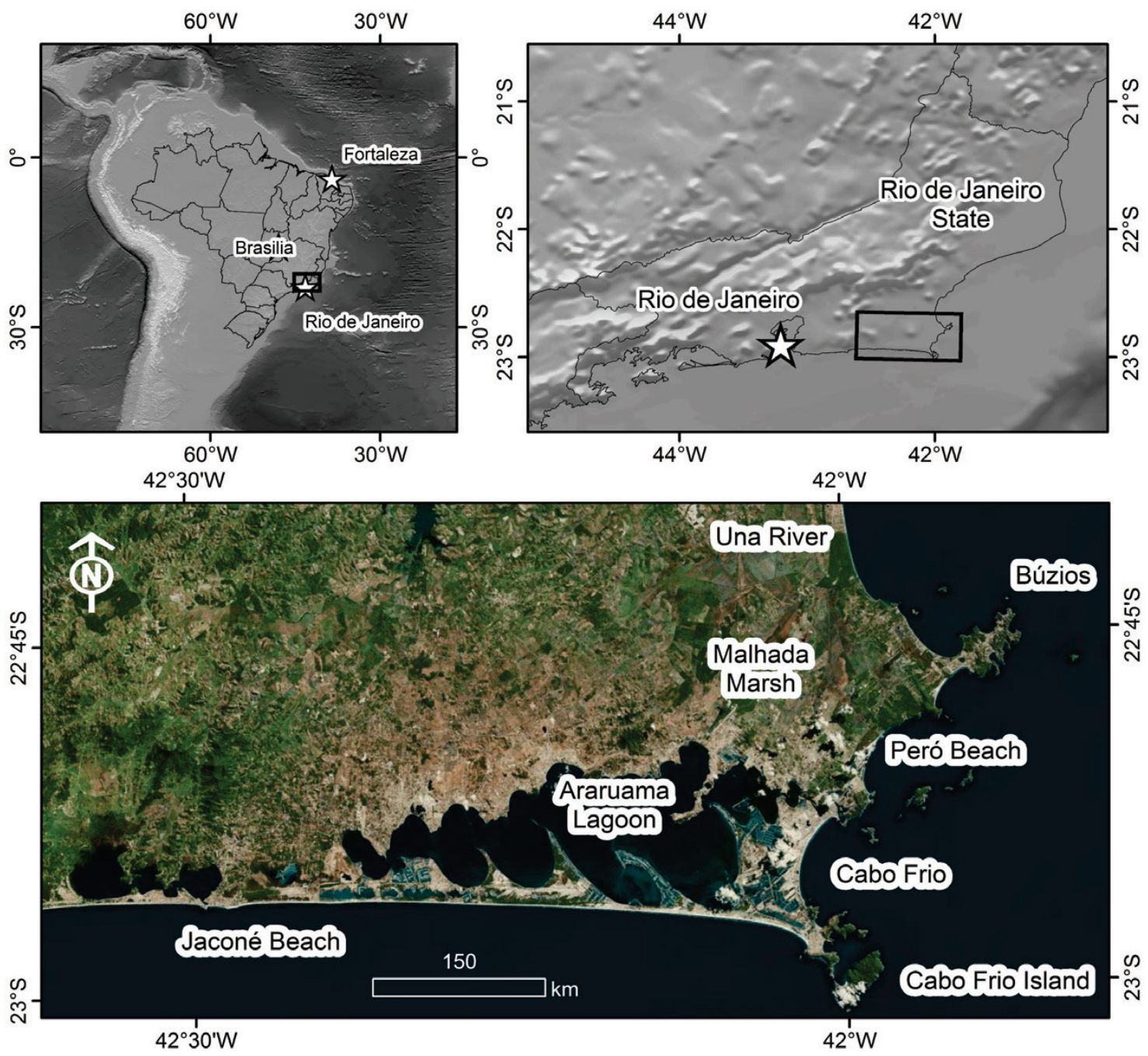

Figure 1 - Location of the study area in the state of Rio de Janeiro, southeastern Brazil. 


\section{MATERIALS AND METHODS}

TOPOGRAPHIC SURVEY

The topographic data and coordinates $(\mathrm{x}, \mathrm{y})$ were obtained using the Pro Mark 2 GPS tracker. GPS static and kinematic methods were used during this stage of the present study. Collection-point coordinates of the geological and biological materials were obtained by the static method. The kinematic method was employed to survey quoted points to construct the sea-level rise variation (RSL) curve.

The information was processed by the Astech Solutions software. In addition, information was used from the geodetic station "3073 D" of the Brazilian Institute of Geography and Statistics (Instituto Brasileiro de Geografia e Estatística IBGE). To compute the orthometric height of the RSL curve, the following mathematical expression was applied: $\mathrm{H}=\mathrm{h}+\mathrm{N}$, where $\mathbf{h}$ is the ellipsoidal height, $\mathbf{H}$ is the orthometric height, and $\mathrm{N}$ is the geoid undulation.

\section{DRILLING METHOD}

Eight percussion drills were performed perpendicular to the coastline within the study area. The drillings were based on the distance and depth of the sample position relative to the current sealevel, which is defined by the " 3073 D" geodetic station of the Brazilian Institute of Geography and Statistics (IBGE).

\section{BIOLOGICAL INDICATORS IN THE SURFACE WATERS}

Biological indicators were researched in the coastal wetlands near the coastline and rocky shores in direct contact with the ocean. Vermetids, paleobarnacles, sea urchins, logs of wood, and mollusk shells were identified. The depth and altimetric dimensions of the material collected by the Pro Mark 2 GPS tracker (static method) were defined. Living homologs of vermetids and barnacles were used to position the altitude of the samples relative to the current mean sea level. In total, 22 samples were radiocarbon dated.

EMERGED AND SUBMERGED GEOLOGICAL INDICATORS

Three emerged samples and four submerged samples of beachrocks were collected on the Cabo Frio Island (Castro et al. 2012) and on the Jaconé Beach (Mansur et al. 2011) in southeastern Brazil. Sample collection on the Cabo Frio Island was conducted via autonomous diving with a portable echobathymeter. The geographical position of the emerged and submerged outcrops was defined by the Pro Mark 2 GPS tracker. During this research phase, the Enseada do Cabo Frio chart (scale, 1:20,000; Navy of Brazil) was used. Seven samples were analyzed under a petrographic microscope and radiocarbon dated.

DATING OF THE SAMPLES

In total, 29 samples were radiocarbon dated for conventional method, including seven mollusk shell samples, two peat samples, one carbonizedwood trunk sample, nine vermetids samples, one barnacle sample, two organic soil samples, and seven beachrock samples (Fig. 2).

During this research stage, the collected material was sent to Beta Analytic Inc., in Miami, FL, United States and to the Head of Radiation Hygienic Monitoring Laboratory (HRHML) in Kiev, Ukraine.

\section{Curve of the Relative Sea LeVel}

The RSL curve of the Rio de Janeiro coast in southeastern Brazil was obtained from altitude definition (vertical axis) and radiocarbon dating (horizontal axis) of the samples. This information refers to GPS surveys by both static and kinetic methods applied to indicators obtained during field work. The altimetric amplitudes of the testimonies were obtained from the top by subtracting the depth of the geological or biological indicator, thereby allowing for measurement of the associated error. 


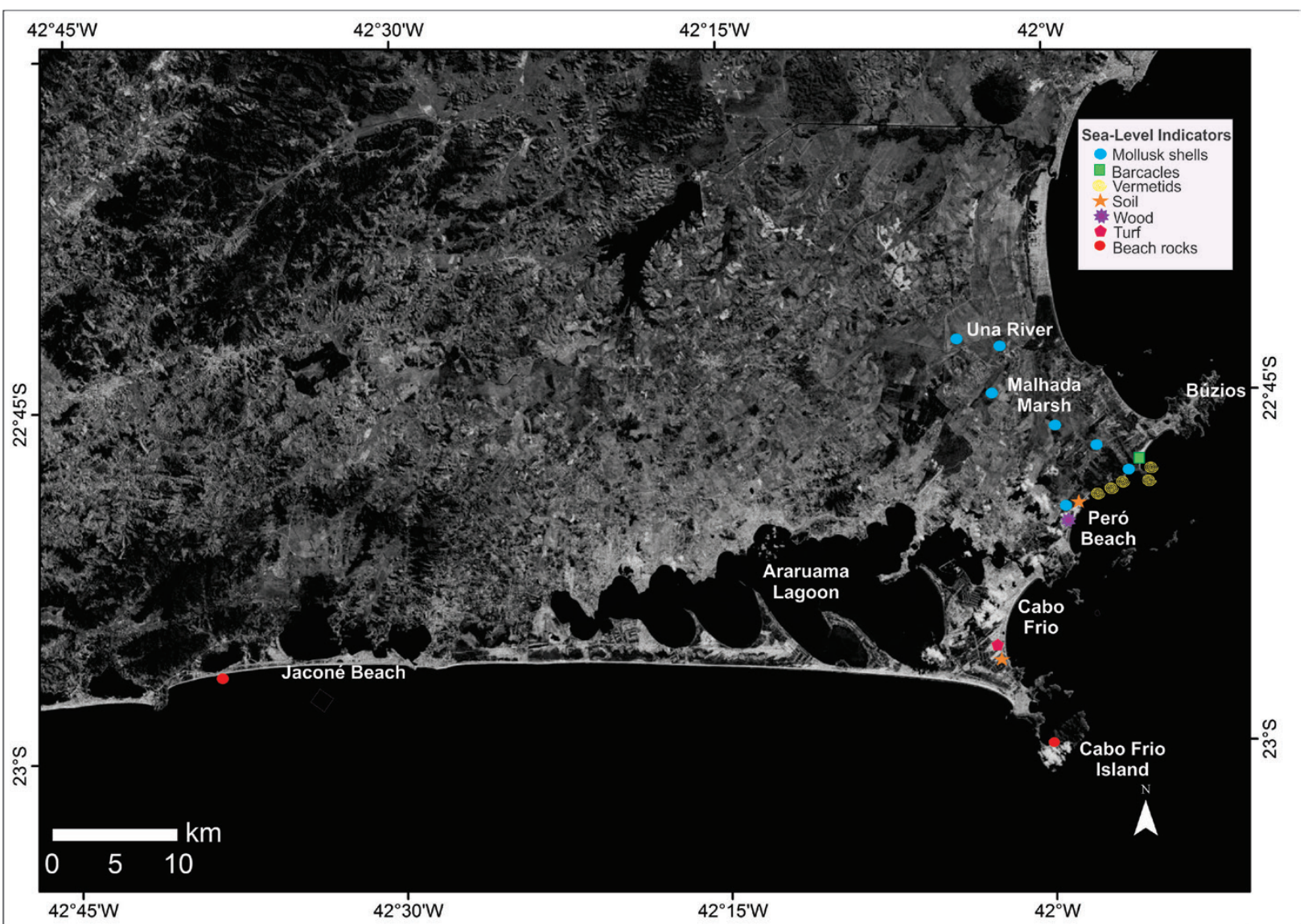

Figure 2 - Location of biological and geological samples in the Fluminenses Lakes region, central coast area in the state of Rio de Janeiro, southeastern Brazil.

The Grapher 6.0 software was used to generate the RSL curve. This tool consists of three spheres: one tabular, another for tabular data and plot manipulation, and finally, the layout. Calibrated sample data were added to two columns: the x-axis for the mean calibrated ages and the $y$-axis for the altitudes of the samples. From the sample values, linear, second-degree polynomial, and fourth-degree polynomial trend lines were generated. In parallel, another curve was generated by averaging the ages calibrated at $2 \sigma$. All of the surveyed altimetric quotes were calibrated with the information obtained between the past and present sea levels. The altitudes of the biological and geological samples for constructing the RSL curve were calibrated using the Datum Imbituba, state of Santa Catarina. The curve error was corrected based on the positioning of living homologs of Laguncularia racemosa (vermetids) and Tetraclita stactifera (barnacle) subjected to a micro-tidal environment.

\section{RESULTS}

Table I presents the laboratory name, the sample height in comparison with the current relative sea level, the type of biological or geological indicator, the geographic coordinates (latitude and longitude), and the conventional age and calibrated age at $2 \sigma$.

\section{DISCUSSION}

Geochronological results obtained from submerged beachrocks suggest that, between 11,940 and 11,240 cal yr BP, the relative sea-level was $4.5 \mathrm{~m}$ below the current (Fig. 3). This time interval locally records the transition between the late Pleistocene and early 
TABLE I

Calibrated ages by ${ }^{14} \mathrm{C}$ dating of the twenty nine samples obtained on the coast of the state of Rio de Janeiro in southeastern Brazil.

\begin{tabular}{|c|c|c|c|c|c|c|}
\hline Sample & Lab. number & $\begin{array}{l}\text { Height } \\
\text { (m) }\end{array}$ & $\begin{array}{l}\text { Sea-level } \\
\text { indicator }\end{array}$ & $\begin{array}{l}\text { Geographic } \\
\text { coordinates }\end{array}$ & $\begin{array}{l}\text { Conventional age } \\
\text { (years B.P.) }\end{array}$ & $\begin{array}{c}\text { Calibrated age } \\
\text { (years cal. B.P. } 2 \text { sigma) }\end{array}$ \\
\hline 1 & $\begin{array}{c}\text { HRHML } \\
\text { (LagecosT 1455) }\end{array}$ & 0.30 & Mollusc shells & $\begin{array}{l}22^{\circ} 44^{\prime} 48^{\prime \prime} \\
41^{\circ} 51^{\prime} 52^{\prime \prime}\end{array}$ & $5070+70$ & $5287-5573$ \\
\hline 2 & $\begin{array}{c}\text { HRHML } \\
\text { (Lagecost 1456) }\end{array}$ & 0.65 & Mollusc shells & $\begin{array}{l}22^{\circ} 44^{\prime} 46^{\prime \prime} \\
41^{\circ} 52^{\prime} 53^{\prime \prime}\end{array}$ & $5540+75$ & $5734-6132$ \\
\hline 3 & $\begin{array}{c}\text { HRHML } \\
\text { (Lagecost 1457) }\end{array}$ & 1.40 & Soil & $\begin{array}{l}22^{\circ} 52^{\prime} 45^{\prime}, \\
42^{\circ} 01^{\prime} 05^{\prime}\end{array}$ & $5830+80$ & $6399-6754$ \\
\hline 4 & $\begin{array}{c}\text { HRHML } \\
\text { (Lagecost 1458) }\end{array}$ & 1.0 & Turf & $\begin{array}{l}22^{\circ} 52^{\prime} 03^{\prime \prime} \\
42^{\circ} 01^{\prime} 02^{\prime \prime}\end{array}$ & $6230+150$ & $6730-7418$ \\
\hline 5 & $\begin{array}{c}\text { HRHML } \\
\text { (Lagecost 1459) }\end{array}$ & 1.10 & Turf & $\begin{array}{l}22^{\circ} 52^{\prime} 04^{\prime \prime} \\
42^{\circ} 01^{\prime} 05^{\prime \prime}\end{array}$ & $6340+85$ & $6989-7418$ \\
\hline 6 & $\begin{array}{c}\text { HRHML } \\
\text { (Lagecost 1500) }\end{array}$ & - & Soil & $\begin{array}{l}22^{\circ} 52^{\prime} 48^{\prime \prime} \\
42^{\circ} 01^{\prime} 06^{\prime \prime}\end{array}$ & $6870+100$ & $7488-7858$ \\
\hline 5 & $\begin{array}{c}\text { HRHML } \\
\text { (Lagecost 2) }\end{array}$ & 1.60 & Mollusc shells & $\begin{array}{l}22^{\circ} 44^{\prime} 48^{\prime} \\
41^{\circ} 52^{\prime} 53^{\prime \prime}\end{array}$ & $3350+70$ & $3000-3373$ \\
\hline 8 & $\begin{array}{c}\text { HRHML } \\
\text { (Lagecost 3) }\end{array}$ & -0.10 & Wood & $\begin{array}{l}22^{\circ} 52^{\prime} 44^{\prime} \\
42^{\circ} 01^{\prime} 06^{\prime \prime}\end{array}$ & $5910+55$ & $6497-6794$ \\
\hline 9 & $\begin{array}{c}\text { HRHML } \\
\text { (Lagecost 11A) }\end{array}$ & 1.50 & Vermetid & $\begin{array}{l}22^{\circ} 44^{\prime} 47^{\prime \prime} \\
41^{\circ} 52^{\prime} 53^{\prime \prime}\end{array}$ & $2810+95$ & $2321-2745$ \\
\hline 10 & $\begin{array}{l}\text { Beta Analytic } \\
259845\end{array}$ & 1.43 & Vermetid & $\begin{array}{l}22^{\circ} 44^{\prime} 51^{\prime \prime} \\
41^{\circ} 52^{\prime} 49^{\prime \prime}\end{array}$ & $3050+80$ & $2683-3050$ \\
\hline 11 & $\begin{array}{l}\text { Beta Analytic } \\
259845\end{array}$ & 1.31 & Vermetid & $\begin{array}{l}22^{\circ} 44^{\prime} 45^{\prime \prime} \\
41^{\circ} 52^{\prime} 57^{\prime \prime}\end{array}$ & $2760+70$ & $2325-2686$ \\
\hline 12 & $\begin{array}{l}\text { Beta Analytic } \\
259847\end{array}$ & 1.81 & Vermetid & $\begin{array}{l}22^{\circ} 44^{\prime} 48^{\prime \prime} \\
41^{\circ} 52^{\prime} 51^{\prime \prime}\end{array}$ & $2890+60$ & $2453-2780$ \\
\hline 13 & $\begin{array}{l}\text { Beta Analytic } \\
259848\end{array}$ & 1.38 & Vermetid & $\begin{array}{l}22^{\circ} 44^{\prime} 43^{\prime \prime} \\
41^{\circ} 52^{\prime} 50^{\prime \prime}\end{array}$ & $2760+70$ & $2325-2686$ \\
\hline 14 & $\begin{array}{l}\text { Beta Analytic } \\
259849\end{array}$ & 2.0 & Barnacle & $\begin{array}{l}22^{\circ} 52^{\prime} 47^{\prime \prime} \\
42^{\circ} 01^{\prime} 08^{\prime \prime}\end{array}$ & $3820+70$ & $3581-3.960$ \\
\hline 15 & $\begin{array}{l}\text { Beta Analytic } \\
259850\end{array}$ & 2.5 & Vermetid & $\begin{array}{l}22^{\circ} 52^{\prime} 41^{\prime \prime} \\
42^{\circ} 01^{\prime} 03^{\prime \prime}\end{array}$ & $4400+60$ & $4409-4771$ \\
\hline 16 & $\begin{array}{l}\text { Beta Analityc } \\
262078\end{array}$ & 1.37 & Vermetid & $\begin{array}{l}22^{\circ} 52^{\prime} 40^{\prime \prime} \\
42^{\circ} 01^{\prime} 09^{\prime \prime}\end{array}$ & $2350+70$ & $1798-2153$ \\
\hline 17 & $\begin{array}{l}\text { Beta Analytic } \\
270651\end{array}$ & 0.85 & Vermetid & $\begin{array}{l}22^{\circ} 47^{\prime} 19^{\prime \prime} \\
41^{\circ} 55^{\prime} 57^{\prime \prime}\end{array}$ & $1410+40$ & $1040-890$ \\
\hline 18 & $\begin{array}{c}\text { Beta analytic } \\
270650\end{array}$ & 0.90 & Vermetid & $\begin{array}{l}22^{\circ} 47^{\prime} 19^{\prime \prime} \\
41^{\circ} 55^{\prime} 57^{\prime \prime}\end{array}$ & $1540+40$ & $1180-1000$ \\
\hline 19 & $\begin{array}{l}\text { Beta Analytic } \\
262079\end{array}$ & 0.94 & Mollusc shells & $\begin{array}{l}22^{\circ} 44^{\prime} 41^{\prime \prime} \\
41^{\circ} 55^{\prime} 56^{\prime \prime}\end{array}$ & $5780+70$ & $5997-6335$ \\
\hline 20 & $\begin{array}{l}\text { Beta Analytic } \\
248721\end{array}$ & -4.5 & $\begin{array}{l}\text { Beachrock } \\
\text { Shell }\end{array}$ & $\begin{array}{l}22^{\circ} 57^{\prime} 59^{\prime \prime} \\
42^{\circ} 01^{\prime} 41^{\prime \prime}\end{array}$ & $10460+70$ & $11940-11240$ \\
\hline 21 & $\begin{array}{l}\text { Beta Analytic } \\
243863\end{array}$ & $-3,0$ & $\begin{array}{l}\text { Beachrock } \\
\text { Shell }\end{array}$ & $\begin{array}{l}22^{\circ} 01^{\prime} 41^{\prime \prime} \\
42^{\circ} 01^{\prime} 41^{\prime \prime}\end{array}$ & $10250+50$ & $11149-11.337$ \\
\hline 22 & $\begin{array}{l}\text { Beta Analytic } \\
248722\end{array}$ & 0.0 & $\begin{array}{l}\text { Beachrock } \\
\text { Shell }\end{array}$ & $\begin{array}{l}22^{\circ} 01^{\prime} 42^{\prime \prime} \\
42^{\circ} 00^{\prime} 42^{\prime \prime}\end{array}$ & $7090+60$ & $7910-7690$ \\
\hline 23 & $\begin{array}{l}\text { Beta Analytic } \\
248723\end{array}$ & 1.5 & $\begin{array}{l}\text { Beachrock } \\
\text { Shell }\end{array}$ & $\begin{array}{l}22^{\circ} 01^{\prime} 42^{\prime \prime} \\
42^{\circ} 01^{\prime} 42^{\prime \prime}\end{array}$ & $3210+80$ & $3130-2860$ \\
\hline 24 & $\begin{array}{c}\text { Beta Analytic } \\
310447\end{array}$ & 0.50 & Mollusc shells & $\begin{array}{l}22^{\circ} 45^{\prime} 49^{\prime \prime} \\
41^{\circ} 57^{\prime} 27^{\prime \prime}\end{array}$ & $5460+40$ & $6190-6330$ \\
\hline 25 & $\begin{array}{l}\text { Beta Analytic } \\
332410\end{array}$ & 0.50 & Mollusc shells & $\begin{array}{l}22^{\circ} 52^{\prime} 24^{\prime \prime} \\
42^{\circ} 20^{\prime} 36^{\prime \prime}\end{array}$ & $2500+30$ & $2270-2090$ \\
\hline
\end{tabular}


TABLE I (continuation)

\begin{tabular}{|c|c|c|c|c|c|c|}
\hline Sample & Lab. number & $\begin{array}{l}\text { Height } \\
\text { (m) }\end{array}$ & $\begin{array}{l}\text { Sea-level } \\
\text { indicator }\end{array}$ & $\begin{array}{l}\text { Geographic } \\
\text { coordinates }\end{array}$ & $\begin{array}{l}\text { Conventional age } \\
\text { (years B.P.) }\end{array}$ & $\begin{array}{c}\text { Calibrated age } \\
\text { (years cal. B.P. } 2 \text { sigma) }\end{array}$ \\
\hline 26 & $\begin{array}{l}\text { Beta Analytic } \\
332411\end{array}$ & - & Mollusc shells & $\begin{array}{l}22^{\circ} 44^{\prime} 52^{\prime \prime} \\
41^{\circ} 52^{\prime} 57^{\prime \prime}\end{array}$ & $5490+30$ & $5910-5830$ \\
\hline 27 & $\begin{array}{l}\text { Beta Analytic } \\
\quad 332412\end{array}$ & - & Mollusc shells & $\begin{array}{l}22^{\circ} 44^{\prime} 49^{\prime \prime} \\
41^{\circ} 52^{\prime} 48^{\prime \prime}\end{array}$ & $5000+30$ & $5430-5280$ \\
\hline 28 & $\begin{array}{l}\text { CAIS - Georgia } \\
\text { University } \\
\text { Marsur et al. (2011) }\end{array}$ & 0.0 & $\begin{array}{c}\text { Beachrock } \\
\text { Cement }\end{array}$ & $\begin{array}{l}22^{\circ} 55^{\prime} 58^{\prime \prime} \\
42^{\circ} 34^{\prime} 04^{\prime \prime}\end{array}$ & $7410+30$ & $6008-5786$ \\
\hline 29 & $\begin{array}{c}\text { CAIS - } \\
\text { GeorgiaUniversity } \\
\text { Marsur et al. (2011) }\end{array}$ & -0.5 & Mollusc shells & $\begin{array}{l}22^{\circ} 55^{\prime} 58^{\prime \prime} \\
42^{\circ} 34^{\prime} 04^{\prime \prime}\end{array}$ & $9190+30$ & $8198-7827$ \\
\hline
\end{tabular}

Holocene on the coast of the state of Rio de Janeiro, southeastern Brazil. Analysis of Rhodophyta, genus Spongites (Kützing, 1847), in the beachrock samples collected between -4.5 and -3.0 m indicate a depositional environment in tropical waters with temperatures above $23^{\circ} \mathrm{C}$, between the late Pleistocene and early Holocene (Castro et al. 2012). These water paleo-temperatures above $23^{\circ} \mathrm{C}$ are markedly different from the current records, in which the average is approximately $18^{\circ} \mathrm{C}$ due to the coastal upwelling phenomenon. During this time interval, the process of beachrock lithification occurred in water conditions much warmer than the current. According to Mabesoone (1964), lithification is caused by contact of the groundwater with seawater, thereby dissolving the carbonate present in the sediments, which are precipitated in the form of calcite.

The upwelling zone of the Arraial do Cabo coast (Cabo Frio Island), Brazil, in the early Holocene, was located far from the current position (Andrade 2008). Beachrocks outcrop at several locations on the coast of the state, especially in the sector facing the south quadrant. It was possible to recognize five lines of parallel beachrocks: one emerged at $1.5 \mathrm{~m}$ above the current average, one emerged at the level of the current beach at $0.0 \mathrm{~m}$, and the other three were submerged at the bathymetric quotes of $-0.5,-3.0$, and $-4.5 \mathrm{~m}$.
The ages range from 11,940 to $3130 \mathrm{cal} \mathrm{yr}$ BP (Table I). The beachrocks that are exposed at the current beach surface correspond to the "zero" reference level (current mean sea level), as determined by geodetic station "3073 D" of the Brazilian Institute of Geography and Statistics - IBGE. The sedimentological and stratigraphic characteristics of the beach environment, which include a tabular morphology with smooth dips below $>3^{\circ}$ and a micro-tidal regime with variations of $<1.0 \mathrm{~m}$ on the coast of the state of Rio de Janeiro, confer accuracy to these rocks as indicators of the mean sea-level. Various researchers have used beachrocks to rebuild RSL curves, mainly in microtidal and mesotidal regions (Kindler and Bain 1993, Dickinson 2001, Bezerra et al. 2003, Caldas et al. 2006).

The studies of relative sea-level variations conducted by Suguio et al. (1985), Angulo and Lessa (1997), and Bezerra et al. (2003) do not provide information on the time interval involving the Pleistocene - Holocene transition because of the absence of geological and biological indicators with ages within this period in a large portion of the Brazilian coast. During the Pleistocene Holocene transition, the relative sea-level at the southeastern Brazilian coast was $4.5 \mathrm{~m}$ below the current (Fig. 4). After the transition, a relatively rapid rise began. At approximately $8500 \mathrm{cal} \mathrm{yr} \mathrm{BP,}$ 

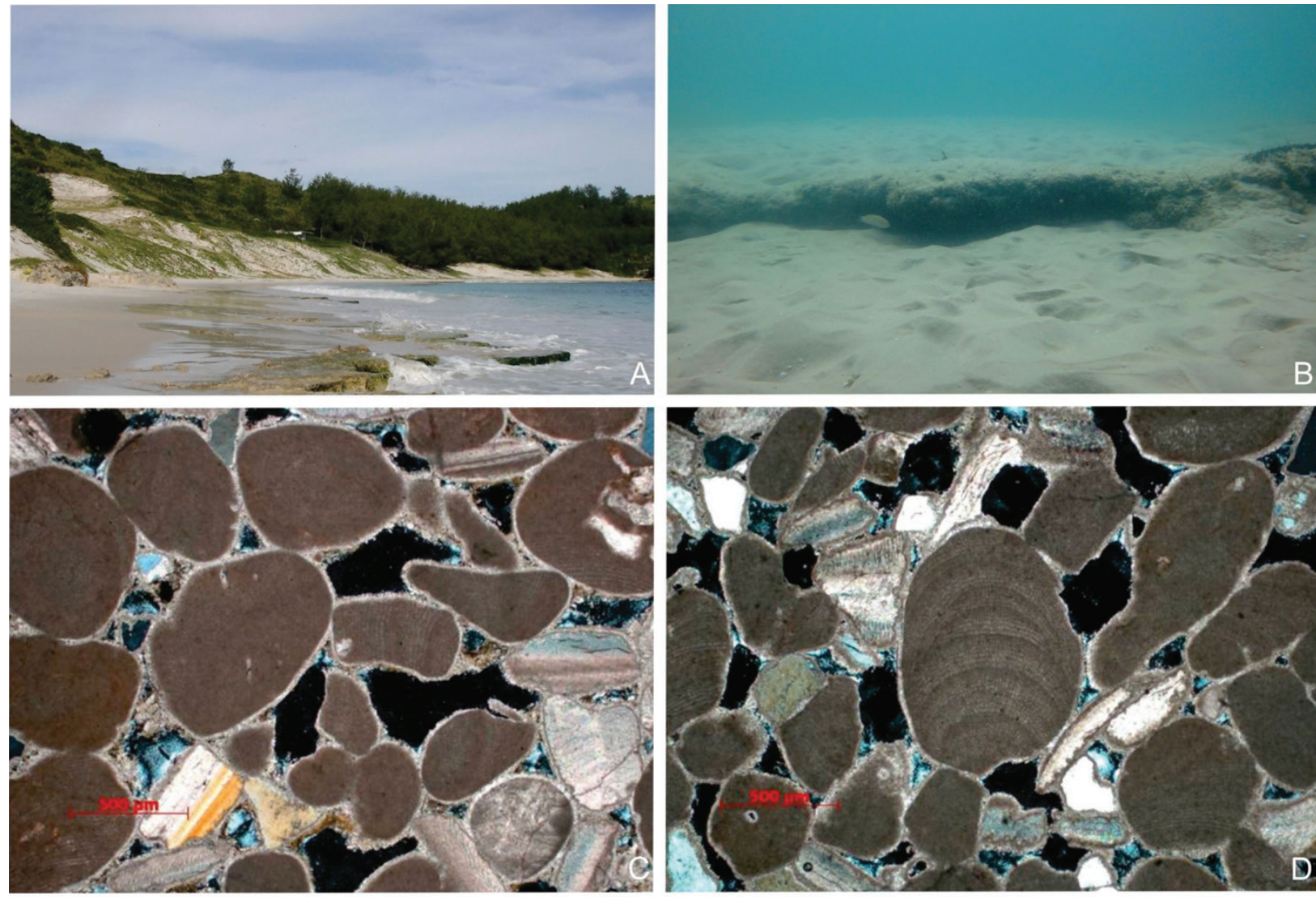

Figure 3 - Occurrence of beachrocks on Cabo Frio Island, southeastern Brazil. A: Beachrocks on the beach surface, at $0.0 \mathrm{~m}$, current mean level (248722 Beta sample dated at 7910 - 7690 cal yr BP [Table I]). B: Beachrock submerged at a depth of $-4.5 \mathrm{~m}$ (248721 Beta sample, dated at 11,940 - 11,240 cal yr BP [Table I]). C and D: Laminar structure demonstrating the occurrence of bioclasts of rounded Rodophyta and angular-to-subangular crystaloclasts.

the sea-level was $0.5 \mathrm{~m}$ below the current level. "Zero" (the current mean level) was overtaken for the first time in the Holocene, at approximately 7500 cal yr BP (Fig. 4). Information obtained in the present study confirms the data obtained by Martin et al. (1985, 1997), and Bezerra et al. (2003) for the Brazilian coast and by Cavalotto et al. (2004) for the Argentinian coast.

Between 5500 and $4500 \mathrm{cal}$ yr BP, the relative sea level (RSL) reached the first Holocene peak with a maximum height of $2.5 \mathrm{~m}$ above the current. This event characterizes the Last Maximum Peak of the Holocene Transgression in southeastern Brazil in the work called "the Cabo Frio transgression" (Fig. 4). Rising sea-levels caused by the transgression caused the region's rivers Una and São João to overflow, thereby transforming their stream mouths into estuaries. Subsequently, barrier islands were formed and, at that time, isolated large lagoon systems (Dias 2009).

The decrease in the relative sea-level following the maximum transgression led to the construction of marine terraces from the original barrier island, resulting in coastline progradation. The lowering of the sea-level caused the gradual transformation of lagoons in ponds; the ponds became brackish marshes and, eventually, fresh water (Suguio et al. 1985). Numerous ponds on the southeastern Brazilian coast present vestiges of much larger, ancient lagoons. During the last 
$1000 \mathrm{cal}$ yr BP, with the relative sea-level at the position of $1.0 \mathrm{~m}$ above the current level, fields of climbing-type dunes were established in the northeastern on the coast of the state of Rio de Janeiro in southeastern Brazil. These fields are currently active (Fig. 4).

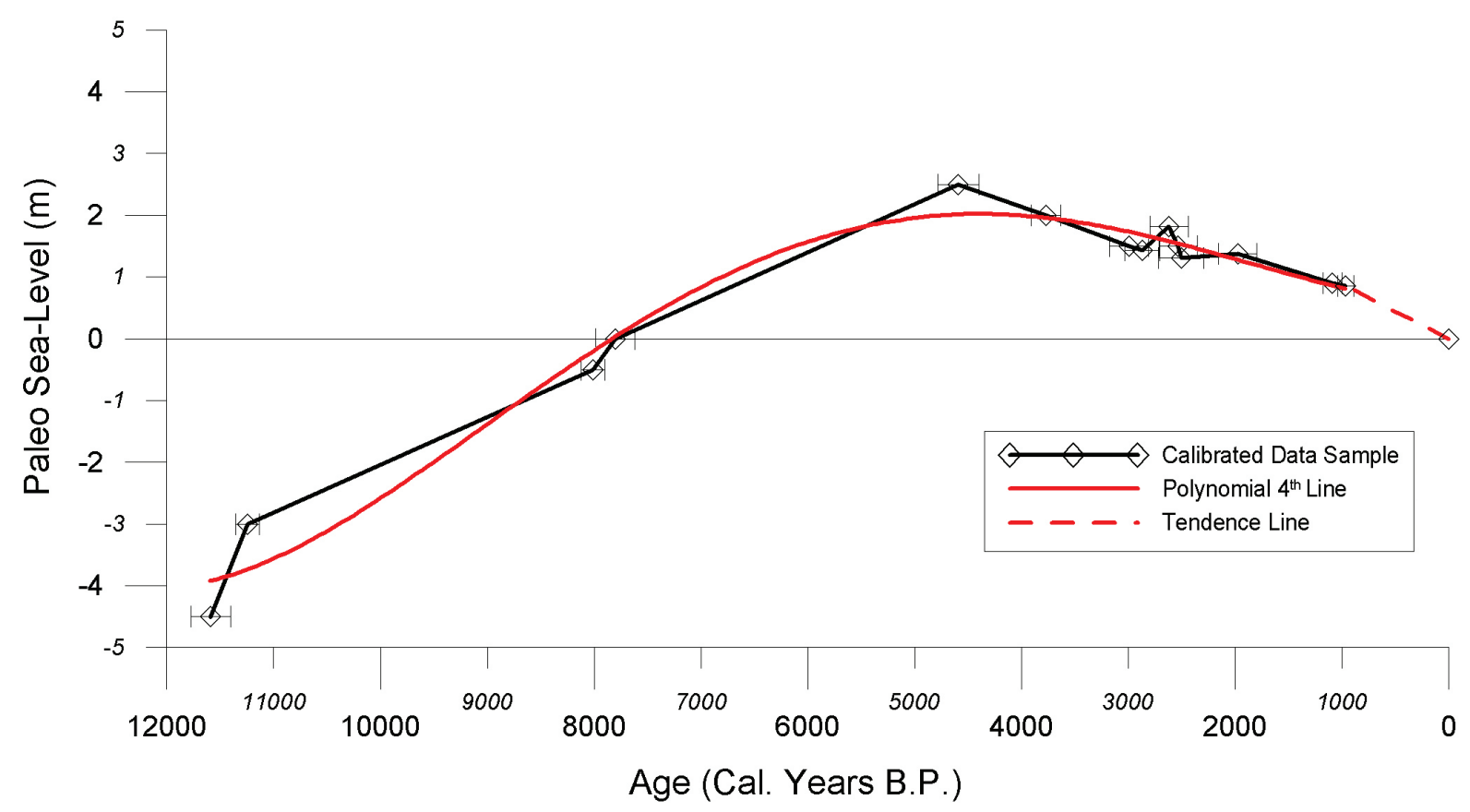

Figure 4 - Relative sea-level variation curve for the coast of the state of Rio de Janeiro, southeastern Brazil. Black Color: Curve constructed from a linear trend line defined by averaging the calibrated ages at $2 \sigma$. Red Color: Curve constructed by a fourthdegree polynomial.

In Fig. 4, the RSL curve for the coast of the Rio de Janeiro, southeastern Brazil, presents a linear trend line defined by averaging the calibrated ages at $2 \sigma$ in (Black Color) and the fourth-degree polynomial in (Red Color). Despite methodological differences between (Black Color) and (Red Color), a general similarity is observed between both curves. The only difference occurs with the Last Great Holocene Transgression - the "Cabo Frio Transgression". In (Red Color), the vertex of the trend line does not correspond to the Maximum Holocene Transgression at 5000 cal yr BP, as documented by Suguio and Martin (1985). In (Black Color), the vertex of the curve is significantly closer to the age that corresponds to this transgression event, which is widely known in Brazil (Martin et al. 1984, Suguio and Martin 1987, Angulo and Lessa 1997, Bezerra et al. 2003).
The GPS trackers employed were highly effective on the coast of the state of Rio de Janeiro determining the altitude (vertical axis) of the samples used for constructing the curve (Fig. 4). The current zero reference (mean sea level) was defined according to the report from the "3073 D" geodetic station of the Brazilian Institute of Geography and Statistics - IBGE. The margin of error for the sample altitudes was minimal. Several investigations conducted on the South American coasts regarding relative sea-level variations have not clearly or precisely defined the reference level of the samples used in the vertical plane (Isla 1989, Angulo and Lessa 1997, Angulo et al. 2002, Cavalotto et al. 2004, Caldas et al. 2006). The absence of this information yields potential inaccuracies regarding the height of the marine paleo-levels of the proposed curves. 
One of the greatest challenges in generating an RSL curve is defining the altitude of the biological and geological samples in reference to "zero" (i.e., the current mean level). In the present work, fouling vermetids, barnacles, and beachrocks were identified precise indicators for defining the marine paleo-levels. Along the rocky coast of the state of Rio de Janeiro, there is representative biological evidence of past sealevels higher than the current level. According to Martin et al. (1985), this evidence is characterized by numerous fouling vermetids, barnacles, and mollusk shells above the current living zone of these species. The fouling vermetids occur in the lower quarter of the intertidal zone, i.e., in the region between the low-tide level of quadrature and the low-tide level of syzygy (Laborel 1979, Laborel and Laborel-Deguem 1986, Angulo et al. 2002). The sea-level indicators, which differ from the current, may be used only when, the altitude of the living homologs representing the evidence or the original altitude of the indicator in reference to the mean sea-level at the time of its formation, are known. Two indicator methods are used to rebuild the marine paleo-levels: comparison with the current forms or comparison with a standardaltitude catalog (Suguio 1999).

In the Malhada Marsh, which is located $10 \mathrm{~km}$ from the current coastline, mollusk shells in the lagoon sediments were identified and radiocarbon dated, yielding ages less than $6300 \mathrm{cal} \mathrm{yr} \mathrm{BP.} \mathrm{The}$ presence of Anomalocardia brasiliana shells in the marshes of the state of Rio de Janeiro, especially in the Malhada Marsh, is caused by the past hypersaline environmental conditions (Cunha 2012). The mollusks species are positioned between 0.30 $\mathrm{m}$ and $0.94 \mathrm{~m}$ above current sea-level. Despite low precision for indicating ancient marine sea-level heights, Anomalocardia brasiliana was critical for understanding the horizontal displacements of paleo-coastlines within the study area. After the "Cabo Frio Transgression" peak, rapid marine regression occurred at approximately $4400 \mathrm{cal}$ years BP. This event documented by Martin et al. (1997) and Castro et al. (2009) was responsible for the generalized mortality of mollusk shells in various segments of the southeastern Brazilian coast, especially in the coastal wetlands of the Cabo Frio region, central coast area in the state of Rio de Janeiro (Fig. 5).
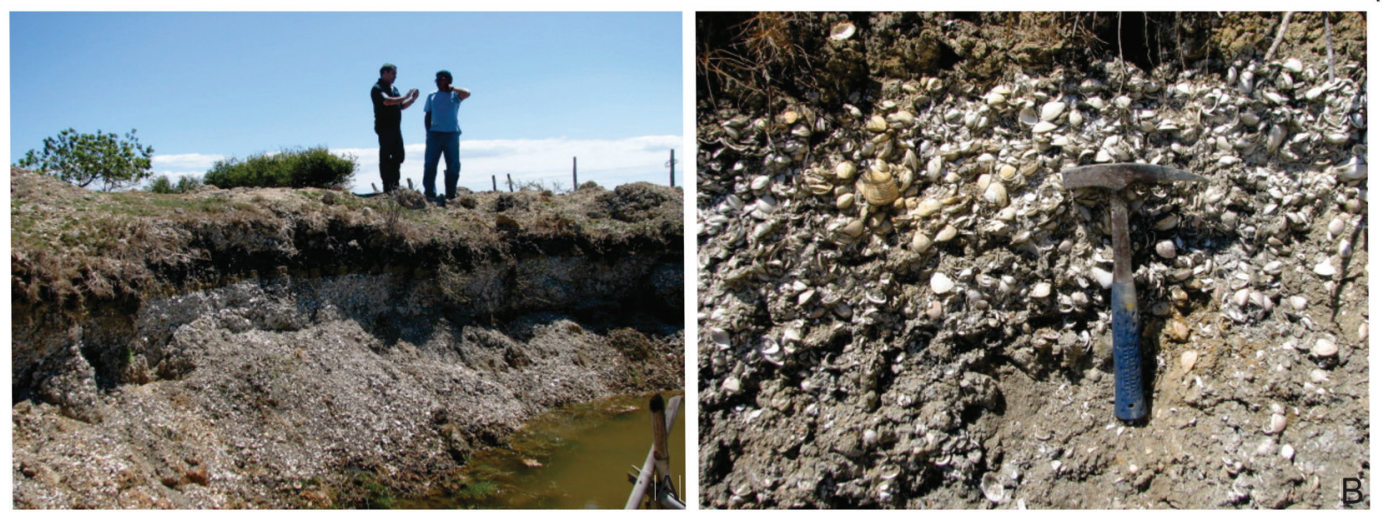

Figure 5 - Overview of mollusk shell deposits dated at 5287 - 5573 cal yr BP (sample HRHML / LAGECOST 1455, Table I) Malhada Marsh, Cabo Frio - southeastern Brazil.

\section{CONCLUSIONS}

All the biological and geological indicators employed in this study were important for rebuilding the ancient positions of the relative sea-level in the horizontal plane; the horizontal (x) axis curves were obtained using both the linear trend line and the average age calibrated at $2 \sigma$. However, the indicators composed of vermetids and barnacles 
(biological indicators) and beachrocks (geological indicators) were accurate for defining the old marine levels, in the vertical projection, using the ordinate (y) axis of the proposed curves. In the bays and inlets of the Rio de Janeiro coast, the living homologs of sea worm snails and barnacles occupy the mean sealevel $(0.0 \mathrm{~m})$. It was possible to distinguish the paleobeach lines within the five beachrock lines. Through analysis of the sedimentary structures and grain size, the sea-level during the deposition process was accurately defined. Because the coastline of the state of Rio de Janeiro is dominated by microtides, with little variation between the maximum and minimum, the margin of error for the sample altitudes was minimal.

The variation curve of the relative sea-level during the last $11,910 \mathrm{cal} \mathrm{yr} \mathrm{BP}$ revealed that, during the Pleistocene - Holocene transition, the sea-level was $4.5 \mathrm{~m}$ below the current. This is the first identified negative sea-level record during Late Pleistocene and Early Holocene transition on the Brazilian coast. At 7500 cal yr BP, the sea-level rise slowed, reaching the current level. The maximum level of $+2.5 \mathrm{~m}$ was reached between 4770 and 4490 cal yr BP. At the point of maximum transgression, the sea-level began a general behavior of lowering until the present. These results confirm other data already obtained elsewhere along the Atlantic coast of South America.

The average rate of relative sea-level variation during the Holocene in the state of Rio de Janeiro coast, southeastern Brazil, was $7.0 \mathrm{~m}$, with a negative variation of $4.5 \mathrm{~m}$ and a positive variation of $2.5 \mathrm{~m}$. Between 11,910 and $7500 \mathrm{cal}$ yr BP, the average rate was $1.2 \mathrm{~mm} / \mathrm{yr}$, with a variation of $1.20 \mathrm{~m}$ within $1000 \mathrm{yr}$. Between 7500 and 4690 cal yr BP, the average rate was $0.87 \mathrm{~mm} / \mathrm{yr}$, with a variation of $0.87 \mathrm{~m}$ within $1000 \mathrm{yr}$. From $4690 \mathrm{cal}$ $\mathrm{yr}$ BP to the present, the lowering of the relative sea level was $0.53 \mathrm{~mm} / \mathrm{yr}$, with a variation of 0.53 $\mathrm{m}$ within $1000 \mathrm{yr}$. Therefore, it is concluded that deceleration of the relative sea-level variation occurred during the Maximum Holocene in the analyzed coastal segment.

There are two direction to be follow in future research which could be a particular value in refining our knowledge of sea-level fluctuations along the southeastern Brazilian coast. Firstly, there is a need to examine, in detail, the evidence for a sea-level low at 11,910 cal yr BP in all regions. Secondly, the method employed in this study would need to be applied to other parts of the Brazilian coastline. This extension should include already studied areas such as the states of São Paulo, Santa Catarina, Bahia and Rio Grande do Norte, but could be extended into states such as Espírito Santo which have not been studied to date. This method may be used to build relative sea-level variation curves for mesotidal and microtidal regions. The method expresses sea-level fluctuations in millimeters to meters, which may be used for current scenarios of the rising or declining sea- levels in Brazil and in the Southern Hemisphere.

\section{ACKNOWLEDGMENTS}

Thanks to the Research Support Fundação Carlos Chagas Filho de Amparo à Pesquisa do Estado do Rio de Janeiaro (FAPERJ) (Case No. E-26/103.311/2011) and the Conselho Nacional de Desenvolvimento Científico e Tecnológico (CNPq) (Case No. 477749/2007) for financial support of the project "Paleo-environmental reconstruction of sea-level variations during the Holocene in the Rio de Janeiro coastline: Integration of geological, biological and archaeological data".

\section{RESUMO}

O presente trabalho tem como objetivo investigar as variações do nível relativo do mar e a evolução costeira durante o Holoceno no litoral do Estado do Rio de Janeiro, com base em indicadores geológicos e biológicos. Realizou-se levantamento altimétrico, execução de sondagens e datações ao $14 \mathrm{C}$ na planície costeira e em afloramentos de rochas de praia. A partir 
dos dados obtidos, construiu-se uma curva do nível relativo do mar para o Holoceno. Pela primeira vez na costa brasileira foi identificado um recorde negativo do nível relativo do mar, envolvendo a transição final do Pleistoceno e início do Holoceno. Após a transição, iniciou-se um processo relativamente rápido de subida do nível do mar. Há aproximadamente 8.500 anos cal A.P., o nível marinho, encontrava-se a - $0.5 \mathrm{~m}$ abaixo do nível atual. O "zero" (nível médio atual) foi ultrapassado pela primeira vez no Holoceno há cerca de 7.500 anos A.P. Entre $5.500-4.500 \mathrm{cal}$ anos A.P, o nível relativo do mar atingiu o primeiro máximo holocênico com altura máxima de $+2.50 \mathrm{~m}$ acima do atual. A descida do nível relativo do mar subseqüente ao máximo transgressivo, levou à construção de terraços marinhos, resultando na progradação da linha de costa até o presente. A maioria dos resultados corroboram dados já obtidos em outros segmentos da costa atlântica da América do Sul. Resultados aqui apresentados são consistentes com pesquisas anteriores e ajudam refinar o registro do nível relativo do mar Holoceno na costa brasileira.

Palavras-chave: Flutuações do nível do mar, Evolução costeira, Holoceno, costa brasileira.

\section{REFERENCES}

ANDRADE MM. 2008. Paleoprodutividade costeira da região de Cabo Frio, Rio de Janeiro, ao longo dos últimos 13.000 anos cal A.P. Unpublished PhD Thesis, Universidade Federal Fluminense, Niterói, 271 p.

ANGUlo RJ AND LeSsA GC. 1997. The brazilian sea level curves: a critical review with emphasis on the curves from Paranaguá and Cananéia regions. Mar Geol 140: 141-166.

Angulo RJ, Pessenda LCR AND Souza MC. 2002. O Significado das Datações ao $14 \mathrm{C}$ na Reconstrução de Paleoníveis Marinhos e na Evolução das Barreiras Quaternárias do Litoral Paranaense. Rev Bras Geoc 32(1): 95-106.

BAKER RGV AND HAWORTH RJ. 2000. Smooth or oscillating late Holocene sea-level curve? Evidence from the palaeozoologyof fixed biological indicators in east Australia and beyond. Mar Geol 163: 367-386.

BELPERIO AP. 1995. The Quaternary. In: Drexel JF and Preiss WV (Eds), The geology of South Australia, vol.2. Geol Soc South Aust Bull 54: 218-281.

BEZERRA FHR, BARRETO AMF AND SUGUIO K. 2003. Holocene sea-level history on the Rio Grande do Norte state coast, Brazil. Mar Geol 196: 73-89.
Caldas LHO, StattegGer K and Vital H. 2006. Holocene sea level history: Evidence from coastal sediments of the northern Rio Grande do Norte Coast, NE Brazil. Mar Geol 228: 39-53.

Castro JWA, Senra MCE And Ramos RRC. 2009. Coquinas da paleolaguna da Reserva Tauá - Pântano da Malhada, Cabo Frio, RJ. In: Winge M, Schobbenhaus C, Souza CRG, Berbet-Born M, Queiroz ET and Campos DA (Eds), Sítios Geológicos e Paleontológicos do Brasil, vol.II, SIGEP, Brasília, Brasil, p. 269-276.

CASTRO JWA AND SUGUIO K. 2010. Holocene and Late Holocene and Late Pleistocene Relative Sea Level Fluctuations in Cabo Frio Island, Rio de Janeiro State - Brazil, In: $4^{\text {th }}$ French Congress on Stratigraphy, Paris, p. 58-61.

Castro JWA, Suguio K, CunhA AM, Guedes E, TÂmegaFTS AND RoDRIGUEZ RR. 2012. Rochas de Praia (Beachrocks) da Ilha do Cabo Frio, Arraial do Cabo: Registro Geológico Ímpar da Transição Pleistoceno - Holoceno no Estado do Rio de Janeiro. Anuário do Instituto de Geociências UFRJ 35(1): 236-241.

CaValotto JL, Violante RA And PARKer G. 2004. Sea-level fluctuations during the last 8600 years in the de la Plata river (Argentina). Quatern Int 114(1): 155-165.

CunHA AM. 2012. Malacofauna das acumulações bioclásticas holocênicas da bacia hidrográfica do rio Una, Cabo Frio e Armação dos Búzios, RJ: Identificação Taxonômica, Considerações Tafonômicas, Paleoambientais e Geocronologia. Unpublished Master Dissertation, Universidade Federal do Rio de Janeiro, Rio de Janeiro, 82 p.

DIAS FF. 2009. Variações do nível relativo do mar na planície costeira de Cabo Frio e Armação dos Búzios, Rio de janeiro: Reconstrução paleoambiental holocênica e cenários futuros. Unpublished $\mathrm{PhD}$ Thesis, Universidade Federal do Rio de Janeiro, Rio de Janeiro, 163 p.

DICKINSON WR. 2001. Paleoshoreline record of relative Holocene sea levels on Pacific Islands. Earth Sci Rev 55: 191-234.

Flexor JM, MARTin L, SUGUIO K AND DOMINGUES JML. 1984. Gênese dos cordões litorâneos da parte central da Costa Brasileira. In: Lacerda LD, Araújo DSD, Cerqueira $\mathrm{R}$ and Turcq B (Orgs), Restingas: Origem, Estrutura, Processos. CEUFF, Universidade Federal Fluminense, Niterói, p. 35-46.

FONSECA RBM. 2012. Evolução batimétrica e sedimentológica do banco de areia "sandbar" da Enseada dos Anjos, Arraial do Cabo, Rio de Janeiro. Unpublished Master Dissertation, Universidade Federal do Rio de Janeiro, Rio de Janeiro, $92 \mathrm{p}$.

GYLLENCREUTZ R, MAHIQUES MM, ALVES DVP AND WAINER IKC. 2012. Mid- to late-Holocene paleoceonographic changes on the southeeastern Brazilian shelf based on grain size records. The Holocene 20(6): 863-875.

ISLA FI. 1989. Holocene sea-level Fluctuations in the Southern Hemisphere. Quatern Sci Rev 8: 359-368.

KINDLER P AND BAIN RJ. 1993. Submerged Upper Holocene on San Salvador Island, Bahamas: Implications for recent sea-level history. Geol Runds 82: 241-427. 
LABOREL J. 1979. Les gasteropodes vermitides: Leur utilisation comme marqueus biologiques de rivages fossiles. Oceanis 5: 221-239.

LABOREL J AND LABOREL-DEGUEM F. 1986. Biological indicators of holocene sea-level and climatic variations on rocky coasts of tropical and subtropical regions. Quatern Int 31: 53-60.

LAMEGO AR. 1945. O homem e o brejo. Serviço Gráfico do IBGE, Rio de Janeiro, Brasil.

MABESOONE JM. 1964. Origin and age of the sandstone reefs of Pernambuco (Northeastern Brazil). J Sed Petrol 34: 715-726.

MANSUR KL, RAMOS RRC, GODOY JMO AND NASCIMENTO VMR. 2011. Beachrock de Jaconé, Maricá e Saquarema - RJ: importância para a história da ciência e para o conhecimento geológico. Rev Bras Geoc 41(2): 290-303.

Martin L, FleXor J-M, BlitzKow D AND Suguio K. 1985. Geoid change indication along the Brazilian coast during the last 7,000 years. In: Coral Reef Congress 5, Tahiti, Proceedings, IGCP, Project 200, 3, p. 85-90.

MARTIN L, FleXor JM AND SUGUIO K. 1984. Enregistrement des périodes de fortes et faibles énergies à l'embouchure d'un fleuve. Le cas du Paraíba do Sul (Brésil). Implications paléoclimatiques. CR Acad Sci II A 299: 661-664.

Martin L, Suguio K AND Dominguez JML. 1997. Geologia do Quaternário Costeiro do litoral Norte do Rio de Janeiro e do Espírito Santo, CPRM, Belo Horizonte, 125 p.

Martin L, Suguio K, Flexor JM And Azevedo AEG. 1988. Mapa Geológico do Quaternário costeiro dos Estados do Paraná e Santa Catarina. Série Geológica DNPM 28: 40.

Miller DE, Yates RJ, PARKington JE AND Vogel JC. 1993. Radiocarbon-dated evidence relating to a mid-Holocene relative high sea-level on the southern Cape Coast, South Africa. South Africa J Sci 89: 35-44.

PORTER SC AND STUIVER M. 1984. Holocene sea-level changes along the strait of Magellan and beagle Channel, Southernmost South America. Quatern Res 22: 59-67.

RAMSAY PJ. 1995. 9000 years of sea-level change along the Southern African coastline. Quatern Int 31: 71-75.

RoncARATI H AND NeVES LE. 1976. Projeto Jacarepaguá. Estudo Geológico Preliminar dos Sedimentos Recentes Superficiais da Baixada de Jacarépagua, Município do Rio de Janeiro - RJ. PETROBRAS \& CENPES. DEXPRO.

SADOWSKI GR AND DiAs NETO CM. 1981. O lineamento sismotectônico do Cabo Frio. Rev Bras Geoc 11(4): 209-212.

SchmitT RS. 2001. A Orogenia Búzios: Um evento tectonometamófico Cambro-Ordoviciano caracterizado no Domínio Tectônico de Cabo Frio, Faixa Ribeira - sudeste do Brasil. 2001. Unpublished PhD Thesis, Universidade Federal do Rio de Janeiro, Rio de Janeiro, 273 p.

SiLva AC. 2009. Dinâmica Batimétrica e Sedimentológica da Região do Cabo Frio - Estado do Rio de Janeiro. Unpublished PhD Thesis, Universidade Federal do Rio de Janeiro, Rio de Janeiro, 157 p.
Silva AC, Castro JWA, Almeida CN AND Dias FF. 2011. Caracterização de minerais pesados na plataforma continental interna de Cabo Frio, Rio de Janeiro, Brasil. Rev DHN 68: 79-87.

Suguio K. 1993. Holocene relative sea-level changes along the Central Brazilian and Japanese Coasts: Possible signifiance of their similarities and diferences. An Acad Bras Cienc 65: 271-278.

Suguio K. 1999. Geologia do Quaternário e mudanças ambientais. Passado + Presente - Futuro. Paulo's Editora, São Paulo, 236 p.

Suguio K. 2003a. Geologia Sedimentar, 1 a . ed., Editora Edgard Blücher, São Paulo, 324 p.

Suguio K. 2003b. Tópicos de geociências para o desenvolvimento sustentável: as regiões litorâneas. Boletim Geologia USP: Série Didática 2(1): 1-40.

Suguio K AND MARTin L. 1985. Classificação de costas e evolução geológica das planícies litorâneas quaternárias do sudeste e sul do Brasil, in: ACIESP (Orgs.), Simpósio de Ecossistemas da Costa Sul e Sudeste Brasileira, Anais 1: $1-28$.

Suguio K AND MARTIN L. 1987. Classificação de costas e evolução geológica das planícies litorâneas quaternárias do sudeste e sul do Brasil. In: ACIESP (Orgs), Simpósio de Ecossistemas da Costa Sul e Sudeste Brasileira, Anais 1: 1-28.

Suguio K, Martin L, BitTencourt ACSP, Dominguez JML, FLEXOR J-M AND AZEVEdo AEG. 1985. Flutuações do nível relativo do mar durante o Quaternário superior ao longo do litoral brasileiro e suas implicações na sedimentação costeira. Rev Bras Geoc 15(4): 273-286.

Suguio K, Martin L And Flexor J-M. 1988. Quaternary sealevels of the Brazilian coast: Recent progress. Episodes 11: 203-208.

Suguio K AND Tessler MG. 1984. Planícies de cordões litorâneos quaternários do Brasil: origem e nomenclatura. In: Lacerda LD, Araujo DSD, Cerqueira R and Turcq B (Eds), Restingas: origem, estrutura, processos, CEUFF, Niterói, p. 15-25.

Turcq B, Martin L, Flexor JL, Suguio K, Pierre C and TASAYACO-ORTEGA L. 1999. Origin and evolution of the Quaternary coastal plain between Guaratiba and Cabo Frio, State of Rio de Janeiro. In: Knoppers BA, Bidone ED and Abrão JJ (Eds), Environmental Geochemistry of Coastal Lagoon Systems, Série Geoquímica Ambiental, EDUFF, Niterói, p.25-46.

VILLWOCK JA. 1994. A costa brasileira: geologia e evolução. Notas Técnicas - UFRGS 7: 38-49.

ZÁLAN PV AND OliveIRA JAB. 2005. Origem e evolução estrutural do Sistema de Riftes Cenozóicos do Sudeste do Brasil. Bol Geoc Petrobras 13(2): 269-300. 